\title{
Kinerja Penyuluh Perikanan Swadaya di Kabupaten Bogor
}

\author{
[Local Fisheries Extension Performance in Bogor Regency] \\ Noor Pitto Sari Nio Lita, Azam Bachur Zaidy ${ }^{\bowtie}$ \\ Sekolah Tinggi Perikanan, Jurusan Penyuluhan Perikanan \\ Jalan Cikaret Nomor 1 Bogor 16001, Jawa Barat \\ Diterima: 25 November 2016; Disetujui: 27 Desember 2016
}

\begin{abstract}
Abstrak
Penelitian dilakukan pada bulan Januari sampai dengan Maret 2016. Penelitian ini bertujuan untuk mengidentifikasi tingkat kinerja Penyuluh Perikanan Swadaya dalam melaksanakan tugasnya, dan untuk menganalisis faktor yang terkait dengan kinerja Penyuluh Perikanan Swadaya Penelitian menggunakan metode pendekatan deskriptif. Metode Pendekatan dekskriptif yang digunakan bersifat kualitatif dan kuantitatif dengan analisis Regresi berganda. Pengumpulan data dilakukan dengan menggunakan kuesioner, wawancara dan studi literatur. Hasil penelitian menunjukkan bahwa tingkat kinerja Penyuluh Perikanan Swadaya di Kabupaten Bogor secara keseluruhan berada dalam kategori relatif baik. Hal ini disebabkan tingginya beberapa aspek kinerja, yaitu: kegiatan penyuluhan, pelaporan dan menyampaikan informasi teknologi. Faktor karakteristik internal Penyuluh Perikanan Swadaya yang mempengaruhi kinerja adalah: tingkat pendidikan formal dan pengalaman usaha, sementara yang tidak mempengaruhi adalah usia dan motivasi. Faktor karakteristik eksternal Penyuluh Perikanan Swadaya yang mempengaruhi kinerja adalah: pemanfaatan sarana dan prasarana, serta dukungan biaya, yang tidak mempengaruhi adalah penghargaan dan jarak tempat tinggal/keterjangkauan. Faktor kompetensi yang berpengaruh terhadap kinerja Penyuluh Perikanan Swadaya adalah kemampuan penguasaan teknologi dan kemampuan bekerjasama, sedangkan pengelolaan program dan kegiatan penyuluhan, serta kemampuan komunikasi tidak mempengaruhi.
\end{abstract}

Kata kunci: karakteristik, kinerja Penyuluh Perikanan Swadaya, kompetensi.

\begin{abstract}
The study was conducted in Januari through Maret 2016. This study aimed to identify the level of performance of local fisheries extension in carrying out their duties, and to analyze factors associated with their performance. This study is descriptive research. Analysis of data done by qualitative and quantitative description with Regression analysis. The data collection was carried out using questionnaires, interviews and study of literature. The results showed that the level of performance of local fisheries extension in Bogor Regency overall performance results are in the relatively good category. its caused by high some aspects of performance, namely: extension activities, reporting and inform the information of technology. Internal characteristics of local fisheries extension factors that affect to the performance are: level of formal education and business experience. Age and motivation not affect. External characteristics of local fisheries extension factors that affect to performance are: the utilization of facilities and infrastructure, support of cost affect was not unidirectional, while awards and affordability of the area where they work not affect. the competency factors that affect to the performance are: the technology skills and ability to work together, while the management of program and extension activities, and the communication skills not affect.
\end{abstract}

Keywords: Characteristics, Competencies, Local Fisheries Extension, Performance 


\section{PENDAHULUAN}

Kinerja seorang penyuluh pada hakikatnya berkorelasi langsung dengan keberhasilan penyuluh upaya dalam menyampaikan tugasnya dalam upaya mengubah perilaku individu, kelompok, atau komunitas masyarakat agar tahu, mau, dan mampu memecahkan masalah yang dihadapi dalam kehidupannya untuk dapat hidup lebih baik. Menurut Marliati et al. (2008), kinerja satuan penyuluhan adalah kinerja yang selalu mengacu kepada konsep pemberdayaan yaitu yang akan mampu meningkatkan kapasitas/keberdayaan dan kemandirian petani. Kinerja penyuluh merupakan capaian hasil kerja penyuluh dalam melaksanakan tugas yang dibebankan kepadanya, didasarkan atas kemampuan, pengalaman, dan atau kesungguhan serta penggunaan waktu (Herbenu, 2007)

Masalah pokok yang selalu dihadapi selama ini adalah terbatasnya tenaga penyuluh perikanan Pegawai Negeri Sipil/PNS yang dibutuhkan sebagai change agent, sehingga kehadiran atau keberadaan para penyuluh swadaya diharapkan dapat untuk memenuhi kebutuhan penyuluh perikanan setempat. Upaya yang dilakukan pemerintah Kabupaten Bogor sebagai upaya mengatasi permasalahan kurangnya tenaga penyuluh yang berasal dari Pegawai Negeri Sipil/PNS adalah dengan langkah pengukuhan pengaktifan Penyuluh Perikanan Swadaya melalui penetapan Keputusan Kepala Badan Ketahanan Pangan dan Pelaksana Penyuluhan Pertanian, Perikanan dan Kehutanan Kabupaten Bogor Nomor: 520/22.a/Kpts/BKP5K/2016 (Anonimus, 2016)

Indikator kinerja para penyuluh perikanan swadaya dapat dilihat pada Lampiran Peraturan Menteri Kelautan dan Perikanan Nomor 31 Tahun 2014 (Anonimus, 2014). Salah satu diantara indikator tersebut adalah kemampuan membuat rencana kerja terkait penyuluhan, melaksanakan penyuluhan dan membuat laporan (Lampiran I). Pada kenyataannya untuk mencapai kinerja penyuluh perikanan swadaya yang memenuhi indikator kinerja tersebut, ternyata banyak ditemui kendala. Keadaan internal dan eksternal penyuluh perikanan swadaya juga dapat menjadi penyebab rendahnya kinerja penyuluh perikanan swadaya (Mardikanto, 2014) 
Tabel 1. Sebaran Responden pada Karakteristik Internal Penyuluh Perikanan Swadaya/PPS

\begin{tabular}{lccc}
\hline Peubah (X1) & Kategori & Jumlah & Persentase \\
\hline Umur & Tua ( $\geq 55$ tahun) & 6 & 20 \\
& Sedang (46-54 tahun) & 7 & 23,33 \\
Pendidikan formal & Muda ( $\mathbf{4} 45$ tahun) & 17 & 56,67 \\
& Rendah (sd. SLTP) & 2 & 6,67 \\
Pelatihan & Sedang (SLTA) & 21 & 70 \\
& Tinggi (Sarjana) & 7 & 23,33 \\
& Teknologi budidaya & 46,66 \\
Pengalaman Usaha & Teknik Penyuluhan & 2 & 6,67 \\
& Tek. Budidaya \& Penyuluhan & 12 & 40 \\
& Belum pernah mengikuti pelatihan & 2 & 6.67 \\
Motivasi & Rendah (S5 tahun) & 2 & 6,67 \\
& Sedang (5-10 tahun) & 11 & 36,67 \\
& Tinggi ( $\geq 10$ tahun) & 17 & 56,67 \\
& Rendah & 2 & 6,67 \\
& Sedang & 8 & 26,67 \\
& Tinggi & 20 & 66,67 \\
\hline
\end{tabular}

Penelitian ini bertujuan untuk: (a) Mengindentifikasi tingkat kinerja penyuluh perikanan swadaya di Kabupaten Bogor termasuk didalam melaksanakan tugas-tugasnya; dan (b) Menganalisis faktor-faktor yang ikut berpengaruh terhadap tahapan kinerja penyuluh perikanan swadaya wilayah Kabupaten Bogor.

\section{BAHAN DAN METODE}

Penelitian ini dilaksanakan di Kabupaten Bogor, pada bulan Januari sampai dengan Maret 2016. Penelitian dilaksanakan menggunakan metode pendekatan deskriptif. Metode dengan Pendekatan dekskriptif yang akan digunakan bersifat kualitatif dan juga kuantitatif. Sampel pada penelitian ini adalah penyuluh perikanan swadaya yang telah/sudah melakukan kegiatan penyuluhan pada bidang budidaya perikanan di Kabupaten Bogor yang berjumlah 30 orang. Data yang dikumpulkan pada kajian ini terdiri dari data primer dan data sekunder.

Data primer yang dikumpulkan melalui pengisisan kuisioner dan wawancara. Untuk melihat pengaruh antar variable, maka digunakan uji statistik"analisis regresi berganda". Reliabilitas diperoleh menggunakan koefisien cronbach alfa yaitu 0,987. Sedangkan untuk uji validitas dengan korelasi r hitung berkisar antara 0.775 
Tabel 2. Sebaran Responden pada Karakteristik Eksternal Penyuluh Perikanan Swadaya/PPS

\begin{tabular}{lcc}
\hline Peubah (X2) & Kategori & Persentase \\
\hline Pemanfaatan Sarana dan prasarana & Tidak pernah & 40 \\
& Jarang & 23,33 \\
& Sering & 36,67 \\
Bantuan Biaya & & \\
1) Biaya operasional & Tidak pernah & 56,67 \\
& Jarang & 43,33 \\
& Sering & 0 \\
2) Insentif/honor & Tidak pernah & 3,33 \\
& Jarang & 0 \\
Penghargaan & Sering & 96,67 \\
& Tidak pernah & 23,33 \\
& Jarang & 43,33 \\
Jarak tempat tinggal (keterjangkauan) & Sering & 33,33 \\
& Dekat & 10 \\
& Sedang & 50 \\
& Jauh & 40 \\
\hline
\end{tabular}

sampai dengan 0,988, sedangkan nilai $\mathrm{r}$ tabel adalah 0,7545 .

Hasil uji normalitas pada data hasil penelitian nilai Sig. berada diantara 0,799 sampai 0,955 lebih besar dari nilai $\alpha=0,05$ yang menunjukan bahwa data berdistribusi normal.

Pada uji multikolinearitas, semua peubah nilai Variance Inflation Factors (VIF) $<10$ dan nilai tolerance $>0,1$. Hal tersebut menunjukan bahwa tidak terjadi multikolinearitas.

Hasil uji autokorelasi data karakteristik internal terhadap kinerja penyuluh perikanan swadaya nilai DW 2,215; data karakteristik eksternal terhadap kinerja penyuluh perikanan swadaya nilai DW 2,310 dan kompetensi terhadap kinerja penyuluh perikanan swadaya dengan nilai DW 1,519. Sedangkan nilai $\mathrm{dl}=1,143$ dan nilai $\mathrm{du}$ $=1,739$. Dari hasil tersebut menunjukan bahwa nampak tidak terjadi autokorelasi untuk karakteristik internal terhadap kinerja penyuluh perikanan swadaya dan kompetensi terhadap kinerja penyuluh perikanan swadaya karena nilai $\mathrm{dl}<\mathrm{DW}<4-\mathrm{du} 2,261$. Namun untuk data karakteristik eksternal terhadap kinerja penyuluh perikanan swadaya dengan nilai 4 -du $\leq \mathrm{DW} \leq 4$-dl tidak menghasilkan kesimpulan yang pasti (inconclusive). Sedangkan Hasil uji heteroskedastisitas, pada semua peubah tidak terjadi 
Tabel 3. Sebaran Responden pada Kompetensi

Penyuluh perikanan Swadaya/PPS

\begin{tabular}{lcc}
\hline Peubah $(\mathrm{X} 3)$ & Kategori & Persentase \\
\hline Pengelolaan program \& kegiatan & & \\
penyuluhan & Tidak kompeten & 3,33 \\
& Kurang kompeten & 23,33 \\
& Kompeten & 73,33 \\
Kemampuan penguasaan teknologi & Tidak kompeten & 3,33 \\
& Kurang kompeten & 46,67 \\
& Kompeten & 50 \\
Kemampuan komunikasi & Tidak kompeten & 0 \\
& Kurang kompeten & 6,67 \\
Kemampuan bekerjasama & Kompeten & 93,33 \\
& Tidak kompeten & 3,33 \\
& Kurang kompeten & 40 \\
& Kompeten & 56,67 \\
\hline
\end{tabular}

heterokedastisitas karena nilai Sig.

Untuk semua peubah lebih besar dari $\alpha=0,05$.sejumlah sisi karakteristik penyuluh swadaya ditunjukkan pada Tabel 1.

Data pada Tabel 1 menunjukkan bahwa: (1) sebagian besar penyuluh perikanan swadaya berusia muda $\leq 45$ tahun; (2) pendidikan formal penyuluh perikanan swadaya mayoritas pada kategori sedang atau sampai pada tingkat Sekolah Lanjutan Tingkat Atas/SLTA; 3) pendidikan informal yang pernah diikuti penyuluh perikanan swadaya mayoritas berupa pelatihan teknis budidaya; (4) pengalaman usaha mayoritas penyuluh perikanan swadaya adalah lebih dari 10 tahun; (5) mayoritas penyuluh perikanan swadaya memiliki motivasi yang tinggi untuk menjadi penyuluh.
Pada Tabel 2 disajikan bahwa (i) pemanfaatan sarana dan prasarana dari pemerintah oleh penyuluh perikanan swadaya cenderung seimbang; Mayoritas penyuluh perikanan swadaya tidak pernah mendapatkan bantuan biaya operasional, tetapi hampir seluruh penyuluh perikanan swadaya atau PPS mendapatkan bantuan biaya dalam bentuk insentif/honor; (iii) mayoritas penyuluh perikanan swadaya jarang menerima penghargaan; dan (iv) mayoritas jarak tempat tinggal penyuluh perikanan swadaya dengan tempat melaksanakan penyuluhan dalam kategori sedang. Pada Tabel 3 disajikan: (1) mayoritas penyuluh perikanan swadaya dalam pengelolaan program dan kegiatan penyuluhan; (2) kompetensi kemampuan penguasaan teknologi oleh para penyuluh perikanan swadaya berada dalam keadaan yang berimbang: 
kemampuan berkomunikasi para penyuluh perikanan swadaya berada dalam katagori kompeten; dan (4) sebagian besar penyuluh perikanan swadaya kompeten dalam kemampuan bekerjasama.

Kinerja adalah hasil kerja yang dapat dicapai oleh seseorang atau sekelompok orang dalam suatu organisasi sesuai dengan tanggungjawab dan kewenangannya berdasarkan tujuan yang telah ditetapkan.

Hasil penelitian pada Tabel 4 mengungkapkan bahwa: (1) mayoritas Penyuluh Perikanan Swadaya berada dalam kategori sedang dalam pembuatan rencana kerja penyuluhan; (2) Penyuluh Perikanan Swadaya berada dalam kategori sedang cendrung tinggi dalam melakukan pelaksanaan penyuluhan perikanan; (3) mayoritas Penyuluh Perikanan Swadaya berada dalam kategori tinggi dalam menyusun laporan bulanan hasil kegiatan penyuluhan; (4) mayoritas Penyuluh Perikanan Swadaya berada dalam kategori sedang hingga tinggi dalam penyampaian informasi teknologi; dan 5) mayoritas responden berada dalam kategori sedang dalam penyampaian informasi pasar.
Total kinerja Penyuluh Perikanan Swadaya dalam penelitian ini adalah keseluruhan hasil kerja seorang penyuluh perikanan swadaya. Hasil penelitian menunjukkan bahwa dari 30 responden sebanyak 50 persen Penyuluh Perikanan Swadaya yang total kinerjanya berkategori tinggi. Hal ini disebabkan oleh tingginya beberapa aspek kinerja yaitu: pelaksanaan, pelaporan, dan informasi teknologi yang disampaikan pada penerima manfaat. Hal tersebut diduga karena; (a) Penyuluh Perikanan Swadaya merupakan ketua kelompok budidaya sehingga setiap program pemerintah selalu bekerjasama dengan ketua kelompok, sehingga Penyuluh Perikanan Swadaya sudah terbiasa menyampaikan informasi tentang program pemerintah kepada anggota kelompoknya dan terbiasa bekerjasama dengan pihak lain terkait usahanya; (2) Penyuluh Perikanan Swadaya dianggap sebagai tokoh/pemuka masyarakat yang telah berpengalaman dalam kegiatan usaha ikan dan relatif sudah berhasil; (3) Penyuluh Perikanan Swadaya memiliki status sosial yang dipandang lebih tinggi, dilihat dari kepemilikan kekayaan/aset, mayoritas Penyuluh Perikanan Swadaya juga memiliki pekerjaan lain seperti 
Tabel 4. Tingkat kinerja Penyuluh Perikanan Swadaya di Kabupaten Bogor tahun 2016

\begin{tabular}{|c|c|c|}
\hline No & Variabel & Persentase \\
\hline 1. & $\begin{array}{c}\text { Rencana kerja } \\
\text { a. } \text { Rendah } \\
\text { b. Sedang } \\
\text { c. Tingqi }\end{array}$ & $\begin{array}{c}0,00 \\
66,67 \\
33,33\end{array}$ \\
\hline 2 & $\begin{array}{l}\text { Pelaksanaan penyuluhan } \\
\text { a. Rendah } \\
\text { b. Sedang } \\
\text { c. Tinqqi }\end{array}$ & $\begin{array}{c}3,33 \\
40,00 \\
56,67\end{array}$ \\
\hline 3. & $\begin{array}{l}\text { Pelaporan } \\
\text { a. Rendah } \\
\text { b. Sedang } \\
\text { c. Tinggi }\end{array}$ & $\begin{array}{c}3,33 \\
36,67 \\
60,00\end{array}$ \\
\hline 4. & $\begin{array}{l}\text { Informasi teknologi } \\
\text { a. Rendah } \\
\text { b. Sedang } \\
\text { c. Tingai }\end{array}$ & $\begin{array}{c}0,00 \\
43,33 \\
56,67\end{array}$ \\
\hline 5. & $\begin{array}{l}\text { Informasi pasar } \\
\text { a. Rendah } \\
\text { b. Sedang } \\
\text { c. Tinggi }\end{array}$ & $\begin{array}{c}3,33 \\
53,33 \\
43,33\end{array}$ \\
\hline 6 & $\begin{array}{l}\text { Total hasil kinerja } \\
\text { a. Rendah } \\
\text { b. Sedang } \\
\text { c. Tingqi }\end{array}$ & $\begin{array}{c}3,33 \\
46,67 \\
50,00\end{array}$ \\
\hline
\end{tabular}

sebagai pensiunan, P2MKP, pengurus UPP, pemuka agama, dan pekerjaannya lainnya. Para Penyuluh Perikanan Swadaya dapat juga dikategorikan sebagai pemimpin opini dalam masyarakat, hal ini sejalan dengan yang dikemukakan Hanan (2005), para pemimpin opini diakui memiliki kredibilitas (keahlian) dalam usaha, memiliki daya tarik (kharisma) bagi pengikutnya, serta memiliki kemampuan yang lebih dalam kegiatan usaha ikan. Selain itu sebagian besar Penyuluh Perikanan Swadaya merupakan penduduk asli sehingga hubungan sosial dan emosional antara Penyuluh Perikanan Swadaya dan pembudidaya binaannya relatif dekat.

\section{Pengaruh Karakteristik Internal dengan Kinerja Penyuluh Perikanan Swadaya}

Hasil analisis Regresi berganda memperlihatkan bahwa karakteristik internal Penyuluh Perikanan Swadaya memberikan pengaruh nyata terhadap kinerja Penyuluh Perikanan Swadaya dengan nilai $\mathrm{f}_{\text {hitung }} 7,141>$ nilai sig 0,001, karena karakteristik internal atau pribadi seseorang merupakan salah satu faktor yang mempengaruhi seseorang dalam pencapaian hasil kerjanya. Hal ini sejalan dengan hasil penelitian Bahua (2010) yang menunjukan adanya pengaruh nyata karakteristik penyuluh dengan kinerja.

Hasil analisis Regresi berganda pendidikan Penyuluh Perikanan Swadaya 
menunjukan bahwa terdapat pengaruh signifikan terhadap kinerja Penyuluh Perikanan Swadaya, nilai Sig. $=0,000$ $<\alpha=0,005$. Pendidikan formal sangat penting bagi jati diri seseorang dalam pengembangan kapasitas diri. Pada umumnya seseorang yang memiliki pendidikan tinggi pada bidang tertentu akan memiliki pengetahuan yang lebih baik dan lebih banyak di bidang tersebut,sehingga akan lebih mudah dan mampu mengkomunikasikan ilmu dan pengetahuannya tersebut dengan baik. Semakin tinggi pendidikan formal, akan semakin tinggi pula kemampuannya untuk menelaah informasi yang diterima dan menerapkan inovasi yang dikenalkan kepadanya. Hal ini sejalan dengan hasil penelitian Hamzah (2011), yang menyatakan bahwa tingkat pendidikan formal berhubungan dengan kinerja penyuluh.

Pengalaman usaha berpengaruh signifikan terhadap kinerja penyuluh perikanan swadaya, dimana nilai Sig. $=0,048<\alpha=0,005$. Pengalaman usaha yang dimiliki oleh Penyuluh Perikanan Swadaya berkaitan dengan kemampuan Penyuluh Perikanan Swadaya dalam penguasaan teknologi budidaya, sehingga akan berdampak langsung pada kinerjanya sebagai seorang penyuluh. Pengalaman usaha sebagai salah satu faktor penting karena semakin lama pengalaman usaha, seorang Penyuluh Perikanan Swadaya akan semakin memahami tentang budidaya ikan sehingga akan berpengalaman dan menunjang dalam melaksanakan fungsi tugasnya sebagai Penyuluh Perikanan Swadaya. Senada dengan hasil penelitian Sapar (2011) menyatakan pengalaman dapat mempengaruhi kinerja seseorang dalam melaksanakan dan menyelesaikan pekerjaannya, demikian juga yang dikemukakan oleh Fatchiya (2010), pengalaman usaha yang dimiliki seseorang dapat berhubungan dengan kemampuan menjalankan usahanya, karena selama masa menjalankan usaha orang tersebut akan mengalami proses pembelajaran dan cara mengatasi permasalahan yang dihadapi.

Kisaran Umur Penyuluh Perikanan Swadaya (nilai Sig. $=0,499$ ) dan motivasi (nilai Sig. $=0,688$ ) tidak berpengaruh terhadap kinerja Penyuluh Perikanan Swadaya. Hal ini menunjukkan bahwa penyuluh perikanan swadaya di Kabupaten Bogor masih sangat produktif dalam melakukan tugasnya sebagai penyuluh perikanan dan ternyata mudah untuk menyerap pengetahuan dan teknologi baru di bidang perikanan yang menunjang kemampuan dalam upaya melaksanakan penyuluhan. hasil penelitian ini sejalan 
dengan hasil penelitian Mujibburahmad (2014), yang juga menyatakan bahwa karakteristik penyuluh dari kategori umur tidak ada hubungan nyata dengan kinerja penyuluh.

Motivasi tinggi yang dimiliki penyuluh perikanan swadaya berasal dari dalam diri penyuluh perikanan swadaya sendiri untuk menjadi seorang penyuluh perikanan swadaya disebabkan beberapa alasan yang melandasinya, diantaranya menjadi seorang penyuluh adalah suatu pekerjaan yang mulia, karena dapat memberikan/berbagi ilmu yang bermanfaat bagi pembudidaya. Keputusan untuk menjadi Penyuluh Perikanan Swadaya merupakan keinginan sendiri secara sukarela untuk menyebarkan pengetahuan dan ketrampilan yang dimilikinya kepada masyarakat. Hal tersebut yang diduga menjadi salah satu penyebab motivasi tidak berhubungan nyata dengan kinerja penyuluh perikanan swadaya. hasil penelitian ini sejalan dengan hasil penelitian Hamzah (2011) yang menyimpulkan bahwa motivasi kerja tidak terdapat hubungan yang nyata dengan kinerja penyuluh.

\section{Pengaruh Karakteristik Eksternal dengan Kinerja Penyuluh Perikanan Swadaya}

Hasil analisis Regresi berganda memperlihatkan bahwa karakteristik eksternal Penyuluh Perikanan Swadaya memberikan pengaruh yang kuat terhadap kinerja Penyuluh Perikanan Swadaya dengan nilai $\mathrm{f}_{\text {hitung }} 11,269>$ nilai sig 0,000, hal ini sama dengan hasil penelitian Mujibburahmad (2014) yang menyatakan terdapat hubungan sangat nyata antara karakteristik eksternal dengan kinerja penyuluh.

Hasil analisis Regresi berganda menunjukan terdapat pengaruh yang nyata antara pemanfaatan sarana dan prasarana dengan kinerja Penyuluh Perikanan Swadaya dengan nilai Sig. < $\alpha 0,05$. Adanya pengaruh pemanfaatan sarana dan prasarana dengan kinerja dapat diduga karena mayoritas Penyuluh Perikanan Swadaya dalam menjalankan tugasnya sebagai penyuluh tidak menggunakan sarana dan prasarana yang dimiliki oleh pemerintah, karena keterbatasannya sarana dan prasarana yang tersedia. Hasil penelitian ini bertentangan dengan hasil penelitian Mujiburrahmad (2014), yang menyatakan tidak ada hubungan yang nyata antara prasarana dan sarana dengan kinerja penyuluh pertanian.

Hasil analisis Regresi berganda menunjukan bahwa bantuan biaya (Sig. $=0,050)$ memberikan pengaruh terhadap kinerja Penyuluh Perikanan Swadaya. Bantuan biaya yang diberikan pemerintah merupakan bentuk perhatian dan 
dukungan terhadap Penyuluh Perikanan Swadaya yang telah menjalankan tugas menjadi penyuluh perikanan dan menjadi pendamping bagi penyuluh perikanan Pegawai Negeri Sipil. Bantuan biaya yang memadai diberikan oleh pemerintah bagi kegiatan penyuluhan yang dilakukan oleh para Penyuluh Perikanan Swadaya diduga dapat meningkatkan kinerja dari para Penyuluh Perikanan Swadaya. Hal tersebut sejalan dengan hasil kajian Indraningsih et al (2010) menyatakan dukungan pemerintah daerah setempat dalam memberikan reward kepada para penyuluh swadaya sangat diperlukan berupa insentif atau honorarium.

Hasil analisis Regresi berganda menunjukan bahwa penghargaan dan jarak tempat tinggal (keterjangkauan) tidak memberikan pengaruh terhadap kinerja Penyuluh Perikanan Swadaya dilihat dari nilai Sig. $=0,762$ dan 0,349. Hal tersebut dapat diartikan bahwa pemberian penghargaan terhadap Penyuluh Perikanan Swadaya bukan hal yang dapat mempengaruhi Penyuluh Perikanan Swadaya dalam menjalankan tugasnya sebagai penyuluh. Adanya pemberian penghargaan atau tidak diberikan penghargaan tidak menjadi hambatan Penyuluh Perikanan Swadaya dalam menjalankan tugasnya. Namun pemberian penghargaan diduga dapat meningkatkan motivasi Penyuluh Perikanan Swadaya untuk memberikan kinerja yang lebih baik. Sependapat dengan substansi tersebut, Sapar (2011) menyatakan penyuluh yang memperoleh pengakuan atau penghargaan akan dapat meningkatkan semangat kerjanya dan Marius et al (2007) adanya penghargaan yang tinggi dari pemerintah dan masyarakat terhadap para penyuluh menempatkan mereka sebagai figur yang populer yang terbuka terhadap berbagai ide dan gagasan serta selalu berinteraksi dengan penerima manfaat dan lembaga atau orang lain yang terkait demi kemajuan.

Jarak tempat tinggal Penyuluh Perikanan Swadaya dengan pembudidaya yang menjadi binaannya, bukan menjadi hambatan Penyuluh Perikanan Swadaya dalam menjalankan tugasnya. Hasil penelitian menunjukkan bahwa mayoritas jarak tempat tinggal Penyuluh Perikanan Swadaya berada pada kategori sedang hingga jauh. Dengan demikian tidak diperoleh jaminan bahwa hadirnya seorang penyuluh yang bertempat tinggal dekat dengan penerima manfaat penyuluhannya maka kinerjanya akan meningkat. Hal tersebut yang diduga menjadi salah satu penyebab faktor keterjangkauan daerah tempat/lokasi bekerja tidak memberikan pengaruh yang signifikan terhadap kinerja 
Penyuluh Perikanan Swadaya. Senada dengan hasil penelitian Bahua (2010), namun berbeda dengan temuan Hamzah (2011) yang menyatakan bahwa jarak tempat bekerja penyuluh berhubungan dengan kinerja penyuluh.

\section{Pengaruh Kompetensi dengan Kinerja Penyuluh Perikanan Swadaya}

Hasil analisi Regresi berganda kompetensi memberikan pengaruh nyata terhadap kinerja Penyuluh Perikanan Swadaya dengan nilai $f_{\text {hitung }}$ sebesar 5,060 dan nilai Sig. sebesar 0,004. Kompetensi yang dimiliki seseorang sangat menentukan pencapaian hasil kerja orang tersebut, karena kompetensi yang dimiliki dapat menjadi alat untuk menduga kemampuan seseorang dalam menyelesaikan pekerjaannya. Hal ini sejalan dengan hasil penelitian Sapar (2011) yang menyatakan bahwa peubah kompetensi penyuluh pertanian berpengaruh nyata terhadap kinerja mereka.

Hasil analisis Regresi kemampuan penguasaan teknologi berpengaruh nyata terhadap kinerja Penyuluh Perikanan Swadaya dengan nilai Sig. $=0,032$. Hal ini didukung dengan hasil penelitian bahwa mayoritas Penyuluh Perikanan Swadaya yang memiliki kemampuan penguasaan teknologi termasuk kategori kompeten. Kompetensi dalam penguasaan teknologi yang dimiliki oleh Penyuluh Perikanan
Swadaya diduga karena rata-rata Penyuluh Perikanan Swadaya di Kabupaten Bogor adalah pelaku utama/usaha yang memiliki pengalaman lama dalam usaha budidaya. Pengalaman yang telah dimiliki penyuluh perikanan swadaya dalam usaha budidaya menyebabkan kemampuan penguasaan teknologi penyuluh perikanan swadaya relatif kompeten, dan ditunjang dengan pelatihan-pelatihan teknis perikanan yang telah diikuti oleh sebagian besar penyuluh perikanan swadaya.

Kemampuan tentang bekerjasama berpengaruh nyata terhadap kinerja penyuluh perikanan swadaya (nilai Sig. $=0,0001)$. Hasil penelitian menunjukan mayoritas penyuluh perikanan swadaya memiliki kemampuan bekerjasama yang baik dan sangat menunjang keberhasilan penyuluh perikanan swadaya dalam menjalankan tugasnya sebagai penyuluh. Hasil penelitian ini sesuai dengan hasil penelitian Mujibburahmad (2014).

Hasil analisis Regresi berganda pengelolaan program dan kegiatan penyuluhan (nilai Sig. $=0,159$ ) serta kemampuan komunikasi (nilai Sig. $=0,510$ ) tidak berpengaruh terhadap kinerja penyuluh perikanan swadaya. Kemampuan komunikasi yang dimiliki penyuluh perikanan swadaya dari hasil penelitian menunjukan kategori kompeten. Kompetensi yang dimiliki penyuluh 
perikanan swadaya dalam berkomunikasi dapat disebabkan karena mayoritas penyuluh perikanan swadaya berasal dari daerah setempat dan beberapa berasal dari daerah lain tetapi sudah lama berdomisili di wilayah tersebut, para Penyuluh Perikanan Swadaya juga sebagai pelaku utama yang memiliki pengalaman cukup lama sehingga memiliki pengetahuan dan keterampilan yang baik di bidangnya. Hal ini yang diduga menyebabkan kemampuan komunikasi tidak memberikan pengaruh nyata terhadap kinerja Penyuluh Perikanan Swadaya.

\section{SIMPULAN DAN SARAN}

\section{Simpulan}

1. Tingkat kinerja Penyuluh Perikanan Swadaya di Kabupaten Bogor secara keseluruhan hasil kinerjanya berada dalam kategori tinggi. Hal ini disebabkan oleh tingginya beberapa aspek kinerja yaitu: pelaksanaan, pelaporan, dan informasi teknologi yang disampaikan pada penerima manfaat.

2. Faktor karakteristik internal yang berpengaruh signifikan terhadap kinerja Penyuluh Perikanan Swadaya adalah pendidikan dan pengalaman usaha, sedangkan umur dan motivasi tidak berpengaruh terhadap kinerja penyuluh perikanan swadaya;
3. Faktor karakteristik eksternal yang berpengaruh signifikan terhadap kinerja Penyuluh Perikanan Swadaya adalah pemanfaatan sarana dan prasarana, serta bantuan biaya, sedangkan yang tidak memberikan pengaruh terhadap kinerja penyuluh perikanan swadaya adalah penghargaan dan jarak tempat tinggal (keterjangkauan);

4. Faktor kompetensi penyuluh perikanan swadaya yang berpengaruh adalah kemampuan penguasaan teknologi dan kemampuan bekerjasama, sedangkan kompetensi pengelolaan program dan kegiatan penyuluhan, serta kemampuan komunikasi tidak memberikan pengaruh pada kinerja Penyuluh Perikanan Swadaya.

\section{Saran}

1. Faktor yang berhubungan dengan pendidikan, punya pengalaman usaha, kemampuan penguasaan teknologi dan kemampuan ikut bekerjasama dapat dijadikan kriteria pada rekruitmen calon penyuluh perikanan swadaya.

2. Peningkatan kinerja para penyuluh perikanan swadaya terwujud dengan menyediakan sarana dan prasarana serta biaya kegiatan penyuluhan. 


\section{DAFTAR PUSTAKA}

Anonimus. 2014. Peraturan Menteri Kelautan dan Perikanan Nomor 31 Tahun 2014

Bahua MI, Jahi A, Asngari PS, Saleh A, dan Purnaba GP. 2010. Faktorfaktor yang mempengaruhi kinerja penyuluh pertanian dan dampaknya pada perilaku petani jagung di Provinsi Gorontalo. Jurnal Ilmiah Agropolitan 3 (1):293-303.

Fatchiya A. 2010. Tingkat kapasitas pembudidaya ikan dalam mengelola usaha akuakultur secara berkelanjutan. Jurnal Penyuluhan Vol. 6 (1):74-83.

Hamzah I. 2011. Faktor penentu kinerja penyuluhan di Kota Tidore Kepulauan Provinsi Maluku Utara. Tesis.Bogor. Sekolah Pasca Sarjana, IPB.

Hanan A, Pulungan I, Lumintang, RWE. 2005. Beberapa faktor yang berhubungan dengan diakuinya seseorang sebagai pemimpin opni dan manfaatnya untuk kegiatan penyuluhan. Jurnal Penyuluhan. Vol. 1 (1): 7-12.

Herbenu PC. 2007. Pengembangan sumberdaya petugas penyuluh lapangan PPL pertanian guna menghadapi persaingan dan meraih peluang kerja. Jurnal Ilmi-Ilmu Pertanian. Vol. 3 (1): 1-11.

Indraningsih $\mathrm{KS}, \mathrm{BG}$ Sugihen, $\mathrm{P}$ Tjitropranoto, PS Asngari, H Wijayanto. 2010. Kinerja penyuluh dari perspektif petani dan eksistensi penyuluh swadaya sebagai pendamping penyuluh pertanian. Jurnal Analisis Kebijakan Pertanian. Vol. 8 (4): 303-321.

Mardikanto T. 2014. Sistem Penyuluhan Pertanian. Surakarta. UNS Press.
Marliati, Sumardjo, Asngari PSA Prabowo, dan Asep. 2008. Faktorfaktor penentu peningkatan kinerja penyuluh pertanian dalam memberdayakan petani: kasus di Kabupaten Kampar Provinsi Riau. Jurnal Penyuluhan. Vol. 4 (2): 9299.

Marius JA, Sumardjo, Slamet M dan Asngari PA. 2007. Pengaruh faktor internal dan eksternal penyuluh terhadap kompetensi penyuluh Di Nusa Tenggara Timur. Jurnal Penyuluhan. Vol. 3 (2): 78-89.

Mujiburrahmad. 2014. Kinerja penyuluh pertanian di Kabupaten Pidie Provinsi Aceh. Tesis. Sekolah Pascasarjana. Institut Pertanian Bogor.

Sapar. 2011. Faktor-faktor yang memengaruhi kinerja penyuluh pertanian dan dampaknya pada kompetensi petani kakao di empat wilayah Sulawesi Selatan. Disertasi. Bogor. Institut Pertanian Bogor. 
Lampiran 1. Peraturan Menteri KP No. 31 tahun 2014

PERATURAN

MENTERI KELAUTAN DAN PERIKANAN REPUBLIK INDONESIA NOMOR 31/PERMEN-KP/2014

TENTANG

PEDOMAN PEMBERDAYAAN PENYULUH PERIKANAN SWASTA DAN PENYULUH PERIKANAN SWADAYA

DENGAN RAHMAT TUHAN YANG MAHA ESA

MENTERI KELAUTAN DAN PERIKANAN REPUBLIK INDONESIA,

\section{BAB II bagian B}

B. Penyuluh Perikanan Swadaya

1. Kedudukan Penyuluh Perikanan Swadaya setara dengan Penyuluh Perikanan PNS dalam melaksanakan kegiatan penyuluhan perikanan, baik sendiri-sendiri maupun kerja sama yang terintegrasi dalam programa penyuluhan perikanan sesuai dengan tingkat administrasi pemerintahan;

2. Tugas pokok Penyuluh Perikanan Swadaya adalah melakukan kegiatan penyuluhan perikanan kepada pelaku utama dan pelaku usaha sesuai dengan rencana kerja penyuluhan perikanan yang disusun berdasarkan programa penyuluhan perikanan di wilayah kerjanya;

3. Untuk dapat melaksanakan tugas pokok, Penyuluh Perikanan Swadaya menyelenggarakan fungsi sebagai berikut:

a. menyusun rencana kerja penyuluhan perikanan yang dikoordinasikan dengan kelembagaan penyuluhan perikanan setempat;

b. melaksanakan kegiatan penyuluhan perikanan sesuai dengan rencana kerja yang telah disusun;

c. mengikuti kegiatan-kegiatan penyuluhan di wilayah kerjanya;

d. melaksanakan pertemuan koordinasi dengan Penyuluh Perikanan PNS, pelaku utama dan pelaku usaha dalam rangka mewujudkan sinergitas kerja;

e. berperan aktif dalam menumbuhkembangkan kelembagaan pelaku utama dan pelaku usaha;

f. menjalin kemitraan dengan Pelaku utama dan pelaku usaha yang mempunyai kompetensi dalam bidang penyuluhan perikanan; 